\title{
SYSTEM ERROR. REFLECTIONS ON THE PERMANENT FAILURE OF TERRITORIALITY OF THE EUROPEAN COHESION POLICY
}

\author{
Teodor Gyelník iD, Gyula Ocskay \\ Central European Service for Cross-Border Initiatives (CESCI) \\ 3. emelet 12/a, Újpesti rakpart 5. 1137 Budapest: Hungary \\ teodor.gyelnik@cesci-net.eu•gyula.ocskay@cesci-net.eu
}

\begin{abstract}
The aim of this article is to generate a debate on the definition and application of the territorial approach of future EU Cohesion Policy. Territorial cohesion, its instruments and tools have formed a specific 'paradigm', 'disciplinary matrix' and 'vocabulary'. However, a peculiar dichotomy resonates: the EU's global economic competitiveness objective is (usually) confronted by its territorial cohesion objectives. Permanent failure is generated and anomalies of the territorial cohesion paradigm are on the rise. Are we at the threshold of a new scientific revolution inside the EU and within its territorial cohesion matrix?
\end{abstract}

Keywords: Cohesion Policy, European Union, Member States, paradigm, scientific revolution, territoriality.

\section{Introduction}

We start our introduction with the famous English tragedy, 'The Tragedy of Hamlet, Prince of Denmark', written by William Shakespeare. When Hamlet speaks with Ophelia, he says, 'And makes us rather bear those ills we have. Than fly to others that we know not of? Thus conscience does make cowards of us all.' (1599-1602/1999, Act III Scene 1).

Hamlet's provocative statement that people tend to accept existing failures and failed structures in spite of the fact that those are already failed and non-functional in their lives. People accept them because they already know the failed system. They know how it works; about its malfunction; and they are afraid to discover unknown territories of life which are probably better than the non-functional one. In other words, 'exploitation' of the existing structures (although inefficient) is easier than 'exploration' of new possibilities (e.g. see March, 1991).

In our article, we write about the system error as a reflection on the permanent failure of territoriality of the European Cohesion Policy. ${ }^{1}$ We understand European Cohesion Policy as a tool that aims to promote harmonious development of regions and Member States of the European

${ }^{1}$ The concept of the current study has been summarised in an easily understandable way as early as 2015 (CESCI, 2015). 
Union (EU). Article 174 of the Treaty on the Functioning of the European Union states that the EU: shall develop and pursue its actions leading to the strengthening of its economic, social and territorial cohesion. In particular, the Union shall aim at reducing disparities between the levels of development of the various regions and the backwardness of the least favoured regions. Among the regions concerned, particular attention shall be paid to rural areas, areas affected by industrial transition, and regions which suffer from severe and permanent natural or demographic handicaps such as the northernmost regions with very low population density and island, cross-border and mountain regions (EU, 2012).

At the beginning of the European integration process, regional policy was not at the forefront of political attention; existing small regional disparities did not call for a distinctive policy intervention. Following the EU enlargements, in 2004 and 2007, however, the share of territories needing development and cohesion were significantly increased.

There is a need to alleviate the differences and disparities in development of the regions and Member States that can generate obstacles to integration and further development. Subsequently, the preamble of the 1957 Treaty of Rome declared: 'to strengthen the unity of their economies and to ensure their harmonious development by reducing the differences existing between the various regions and the backwardness of the less favoured regions.' (EC, 1957). This article is divided into two basic parts. The first part represents a theoretical and philosophical approach toward 'knowledge' and 'scientific revolution'. The former expresses a form of knowledge production, its impurity and its link with power; thus it underlines the importance of narratives on reality, while the latter explains the Kuhnian approach (1962/1970) toward changes within the science and within the established and ruling paradigms.

Part two considers the topic of territorial cohesion and aims to describe the anomalies of Cohesion Policy, its failed interpretation and some reflections on its failure to fulfil those functions which were identified as its goal. The article continues with the different interpretations of territorial cohesion, it presents the great challenge of territoriality and it ends with the model of the 'brick wall' as a necessary paradigm shift in Cohesion Policy.

\section{Knowledge production, impurity and paradigm change}

In the first part of this article, we reflect on the progress of science, taking a theoretical and philosophical approach. This part contains ideas and thoughts about knowledge, power, particularism, development and changes within the realm of science. These issues deeply influence the concepts and narratives which subsequently generate the reality around us.

Why is it important to apply some philosophical and theoretical approaches in this article? The way we define, narrate and/or speak about EU Cohesion Policy determines the method of its implementation in real life and how everyday life is affected. It determines the future of the less developed regions and the future of the European integration project.

The issue of applied narration, definition and mental frames are explicit conceptualisations that generate specific discourse with the ability to constitute the so-called 'knowledge'. As Chris Weedon (1987/1993) underlines, discourses are much more than ways of thinking and producing meaning; they constitute the 'nature' of the body. Thus discourse constitutes knowledge, including social practices, power relations and subjectivity. Foucault puts it $(1972 / 1980$, p. 52) in the following way, 'The exercise of power perpetually creates knowledge and, conversely, knowledge constantly induces effects (...) It is not possible for power to be exercised without knowledge, it is 
impossible for knowledge not to engender power.' This means that mutuality of power-knowledge are directly linked to each other,

[w]e should admit (...); that power and knowledge directly imply one another; that there

is no power relation without the correlative constitution of a field of knowledge, nor any

knowledge that does not presuppose and constitute at the same time power relations

(Foucault, 1978, p. 27).

Simply, how we define the world around us, the way we name it and the way we narrate it constitute the world in which we live and exist.

Moreover, we build on the magnum opus of Thomas Kuhn, namely 'The Structure of Scientific Revolutions' published in 1962, which powerfully stirred the mud within the science itself and generated intensive tensions within the realm of science. Kuhn applied a controversial and provocative idea on the development of science. He articulated the bold idea that the science itself can be defective, can be ill-managed and often ignores new findings and discoveries which may challenge the dominating ideas, opinions and understandings. This means that specific scientific approaches are so internalised, or even dogmatised, that they most often operate and function without anyone noticing their particularistic path and approach. This internalisation of paradigm constitutes the apt term, 'Foucault's laughter', when we discover the limitation of our thinking, the limitation of our rationality and when we become aware that thinking of the 'others' can also be represented, like our own, in a normative way. Foucault (1966/2002, p. xvi) puts it,

in the wonderment of this taxonomy, the thing we apprehend in one great leap, the thing that, by means of the fable, is demonstrated as the exotic charm of another system of thought, is the limitation of our own, the stark impossibility of thinking that.

Nevertheless, in spite of the often repeated idea of the objectivity and neutrality of science, knowledge is hardly an objective issue that has the ability to reflect the overall, uncontaminated and uncorrupted truth. Rather, it is a particularistic approach and understanding of the world around us. Jacques Lacan explains the way that science is characterised by a particular relationship to truth and that this is illegitimate; it monopolises truth as its exclusive property (Evans, 1996).

Thomas McCarthy (2009) notes, every imagination has a certain pre-understanding, specifically, every imagination/idea/theory is built on already existing political/societal/normative preconditions of the society. Hence, every normative idea is inherently impure and contaminated with particularism, thus further obscuring the idea of objectivity and neutrality. This was articulated by Foucault, too: namely that the idea of 'universality' and/or 'true' is historically contingent; those are not universal truths, but rather sets of practices that have influence on our behavior within a specific period (see e.g. Taylor, 2011). Moreover, the already existing political/societal/normative preconditions, which are essentially important elements of knowledge and principally determinants for any change, are described by Johan P. Olsen (2010) as 'genetic soup' and Arthur Stinchcombe (1987) identifies them as 'historicist causal imagery'. This means that institutional change or any re-interpretation of any system is not fully independent; the pre-existing institutional components and/or building blocks heavily determine the path (viability and usability) of any change forming a new structure or reinterpretation of the existing arrangement.

Consequently, we easily tend to forget that the established orders are just 'established orders' (Gregory, 2004, p. 3), which are established by the fundamental codes of culture (Foucault 1966/2002), and nothing more, 'it is a fabrication. This does not mean that it is simply false. On the contrary, it is validated by its own regimes of truth and it produces acutely real, visibly material consequences.' 
This particularistic approach of the 'established orders' is described by different authors under different terms, like 'episteme' that defines the conditions of possibility of all knowledge (Foucault, 1966/2002); 'secular eschatological understanding' (Laclau, 2007); 'conceptual blueprints' (Bell, 2009); or 'archetypical story' (Neumann, 2013). Iver Neumann (2013, p. 150) aptly puts it, 'It is always one's own practices that are perfectly reasonable and easy to account for, whereas the practices of the other seem to be resting in myth and so appear as irrational and even incomprehensible.'

This means that once the order is constructed it uses all the sources to legitimate itself and it becomes so internalised that it becomes 'immune' even to intellectual attacks. Subsequently, the internalised and fabricated order is validated through its own interpretations and conditions.

\section{'Scientific revolution' as modifier of the world around us}

According to Thomas Samuel Kuhn, we can distinguish two phases of science development. One is the normal development phase, the 'normal science' that is characterised as 'puzzle-solving'. At this stage, a specific intellectual framework is generated and labelled as 'scientific consensus', 'set of received beliefs' or 'disciplinary matrix' that establishes values, norms, approaches and methods for science and research. This phase is characterised as (Kuhn, 1962/1970, p. 5):

the activity (...) is predicated on the assumption that the scientific community knows what

the world is like. Much of the success of the enterprise derives from the community's

willingness to defend that assumption, if necessary at considerable cost.

These consensuses, assumptions, beliefs and matrix embody the 'paradigm' itself; but the paradigm has huge conservative power since the educative and implementing institutions are built on the paradigm itself and 'Men whose research is based on shared paradigms are committed to the same rules and standards for scientific practice.' As a consequence, disagreement on the fundamentals is very rare because, 'The man who is striving to solve a problem defined by existing knowledge and technique is not, however, just looking around. He knows what he wants to achieve, and he designs his instruments and directs his thoughts accordingly.' (Kuhn, 1962/1970, p. 96).

At this stage, the research is entirely linked with the matrix. The researcher ('the puzzle-solver') moves within the charted territory of sciences. It can also be called 'business as usual'. Thus it is naturally embedded within the matrix where research is regularly driven by 'problem selection' which can be handled with the conceptual and instrumental techniques of the paradigm. lan Hacking underlines it within his Preface of Kuhn's book (2012, p. xxvi), 'normal science does not aim at novelty but at clearing up the status quo. It tends to discover what it expects to discover'; consequently, no real breakthrough can happen that goes beyond the matrix. Simply, the paradigm-based research attempts to force science, nature and research into an inflexible box, fundamental novelties are not searched. This is what James G. March (1991) calls 'exploitation of old certainties' in organisational learning, namely continuing/exploiting the already existing routines, set of procedures, norms, rules and forms that are combined together in a form of knowledge.

Due to the scientific normative framework and the limited scope of paradigm-based research, anomalies which are in disagreement with the 'disciplinary matrix' start to emerge. 'New and unsuspected phenomena are, however, repeatedly uncovered by scientific research, and radical new theories' (March, 1991, p. 52). The emerging anomalies embody fundamental novelty discoveries, they are either without notice because of 'tunnel vision' or they are stigmatised and suppressed because of their subversive character. Therefore 'novelty emerges only with difficulty, manifested 
by resistance, against a background provided by expectation.' (March, 1991, p. 64). However, the growing number of discrepancies between the matrix and the data generates a tension within the science that sooner or later triggers the 'revolutionary stage' of science: 'scientific revolutions are here taken to be those non-cumulative developmental episodes in which an older paradigm is replaced in whole or in part by an incompatible new one' (March, 1991, p. 92).

The revolutionary phase disrupts the cumulative structure and substantial shifts are introduced. Thus this extraordinary phase often drops many concepts that were important within the pre-revolutionary disciplinary matrix. The new emerging paradigm is incompatible and incommensurable with the one which has gone before; thus (March, 1991, p. 103):

the reception of a new paradigm often necessitates a redefinition of the corresponding science. Some old problems may be relegated to another science or declared entirely "unscientific." Others that were previously nonexistent or trivial may, with a new paradigm, become the very archetypes of significant scientific achievement.

Subsequently, a new and revised disciplinary matrix is established that is able to handle the accumulated anomalies. Kuhn (1962/1970, p. 91) puts it in the following way,

The proliferation of competing articulations, the willingness to try anything, the expression

of explicit discontent, the recourse to philosophy and to debate over fundamentals, all these are symptoms of a transition from normal to extraordinary research.

If a revolutionary shift happens, it changes all the components such as concepts, values, norms, interpretations, normative hierarchies; and naturally it changes the world around us. 'Therefore, when paradigms change, there are usually significant shifts in the criteria determining the legitimacy both of problems and of proposed solutions' (Kuhn, 1962/1970, p. 109).

To conclude the first part of our article (a kind of 'recourse to philosophy'), we consider the Kuhnian approach important because we need to understand that we are often limited with paradigms, scientific consensuses, disciplinary matrixes, discourses, narratives and set of norms and values which do not allow breaking out from the (non-functional) box. These accepted norms, ideas, representations and narratives significantly influence our thinking and they generate how we perceive the world around us. Simply, narratives, creeds and beliefs generate specific mental content - or as Catherine Bell (2009) calls them, 'conceptual blueprints' - which subsequently deeply influence, direct, inspire or encourage activities and actions without being themselves actions. This is what Foucault calls a power-knowledge relationship. Changing the blueprint of our reality, too, or as David Harvey (2011, p. 133) brilliantly writes 'Changing beliefs and values are (...) what really matters. Change the discourses, it is sometimes said, and the world will change, too.'

Consequently, the way we define, narrate and speak about EU Cohesion Policy determines its implementation in real life. If definition and narration of territoriality and cohesion policy are incorrect, ineffective and improper then this ineffectiveness automatically translates into reality and into improper implementation of Cohesion Policy. The anomalies and crises of Cohesion Policy forecast a necessary paradigm shift.

\section{Anomalies of Cohesion Policy}

We adapt Kuhn's paradigm theory to the issue at the very heart of the future of the EU, i.e. Cohesion Policy; more specifically, the territorial aspect of Cohesion Policy. According to the doyen of European spatial planning, Professor Andreas Faludi (2012, p. 15), '[w]ithout cohesion policy, the EU as we know it could well disappear'. In fact, the unique model of economic, social and territo- 
rial cohesion symbolises the realisation of the EU's founding fathers' wish to prevent permanently erupting armed conflicts on the continent and to keep the leading role of Europe in global economic and innovation competition by creating an integration reaching beyond national boundaries.

The reduction of regional disparities has always been a key issue for the Community ever since the Spaak Report (1956) preparing the Treaty of Rome (Faludi, 2009). The Report argued for the establishment of a fund promoting balanced development of the Member States. The Treaty of Rome included this idea via the term of 'harmonious development' (Art (2)). However, at the very beginning the issue was not key for joint policies. The founding states of the Communities were at a similar economic development level and their predominant aim was rather to diminish the existing regional disparities within their own countries by adapting Community level re-distribution quotas and national level distribution models (Rechnitzer \& Smahó, 2011; Svensson \& Balogh, 2018).

This original homogeneity was broken from the 1970s when countries lagging behind in terms of economy or infrastructure joined the Community. New, remarkable disparities between different regions made increasing the weight of regional interventions and embedding them into Community policies inevitable. The embedding process started in 1968 with the set-up of Directorate-General XVI, dedicated to regional development, within the European Commission. At the 1972 Paris summit, the decision was made to establish the European Regional Development Fund which since 1975 provides financial support to interventions targeting the reduction of regional-structural disparities. Through the reform of 1984, the system of automatised nationally distributed quotas was eliminated; while the Community level monitoring system and a new set of tools, the so-called Community Initiatives were launched. These steps obviously marked the naissance of a Community-level regional policy (Rechnitzer \& Smahó, 2011).

When Jacques Delors became the President of the Commission in 1985, he set the ambitious goal to create the European Single Market, meaning the elimination of internal barriers, by 1992 . (Veggeland, 2004; Reitel, Wassenberg \& Peyrony, 2018). The Single European Act (EC, 1987), entered into force in 1987 in compliance with the above goal, made regional policy part of Community policies in a normative way when defining economic and social cohesion (Art (130a)):

In order to promote its overall harmonious development, the Community shall develop and pursue its actions leading to the strengthening of its economic and social cohesion. In particular the Community shall aim at reducing disparities between the various regions and the backwardness of the least-favoured regions.

Accordingly, since then Regional Policy (renamed as Cohesion Policy in the Third Cohesion Report; EC, 2004) has aimed to mitigate regional disparities, i.e. to create the legal, policy and financial background for balanced development of the whole Community. Thanks to the reform of 1988 and the Maastricht Treaty (1993; EU, 1992), Regional Policy became one of the key objectives of the EU, representing one-third of the total budget and developing a permanently broadening institutional system. Regardless of the exemplary efforts in both policy and financial terms however, the main objective of mitigating regional disparities has so far failed.

According to Bachtler, Martins, Wostner and Żuber (2017, p. 2), the gap between the leading (so-called 'frontier') and lagging regions 'has grown by 56 percent between 1995 and 2014'. While some better-off regions (especially those including the capitals and larger cities) equipped with research and educational institutions and infrastructure managed to take the 'innovation train', other areas' backwardness has persevered. The authors add (Bachtler et al., 2017, p. 2):

These differences cannot be addressed by compensatory policies relying on income transfers.

The adaptation to the specific shocks on regional economies generated by globalisation and market integration require differentiated (or place-based) strategies. 
Third report on economic and social cohesion

GDP per head (PPS), 2001 [Map 1.1]

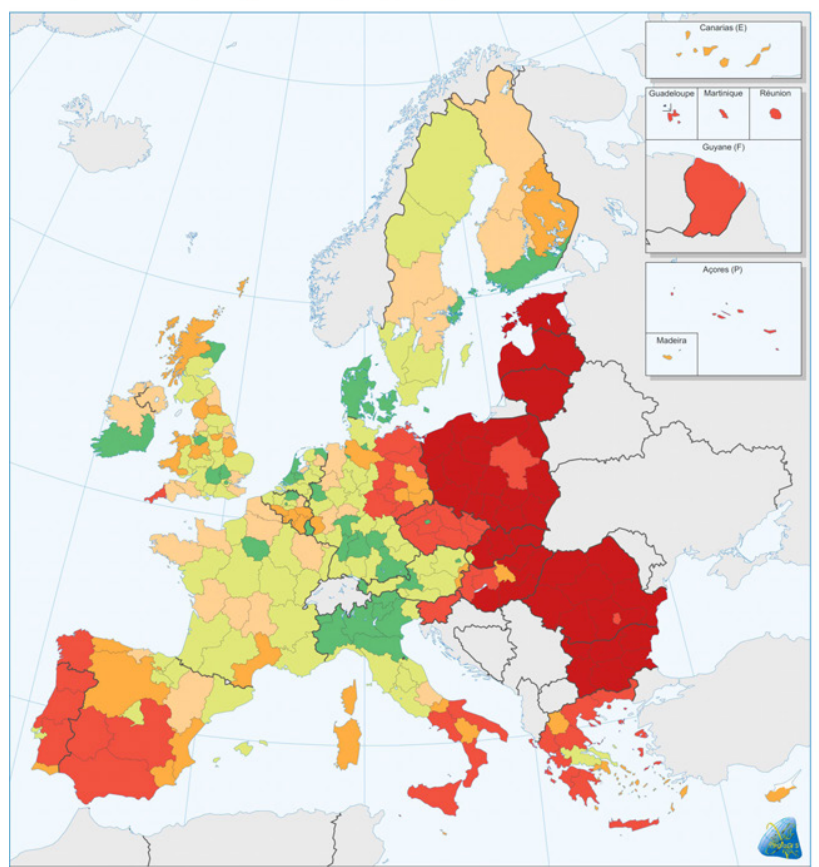

1.1 GDP per head (PPS), 2001

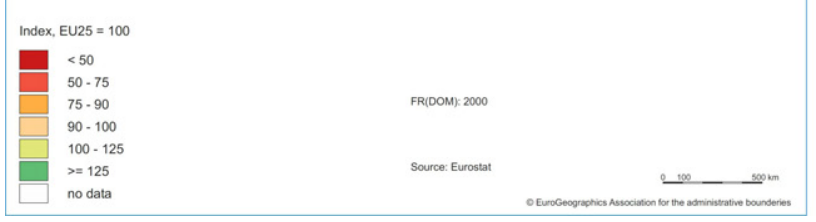

Seventh report on economic, social and territorial cohesion GDP per head (PPS), 2015 [Map 1.1]

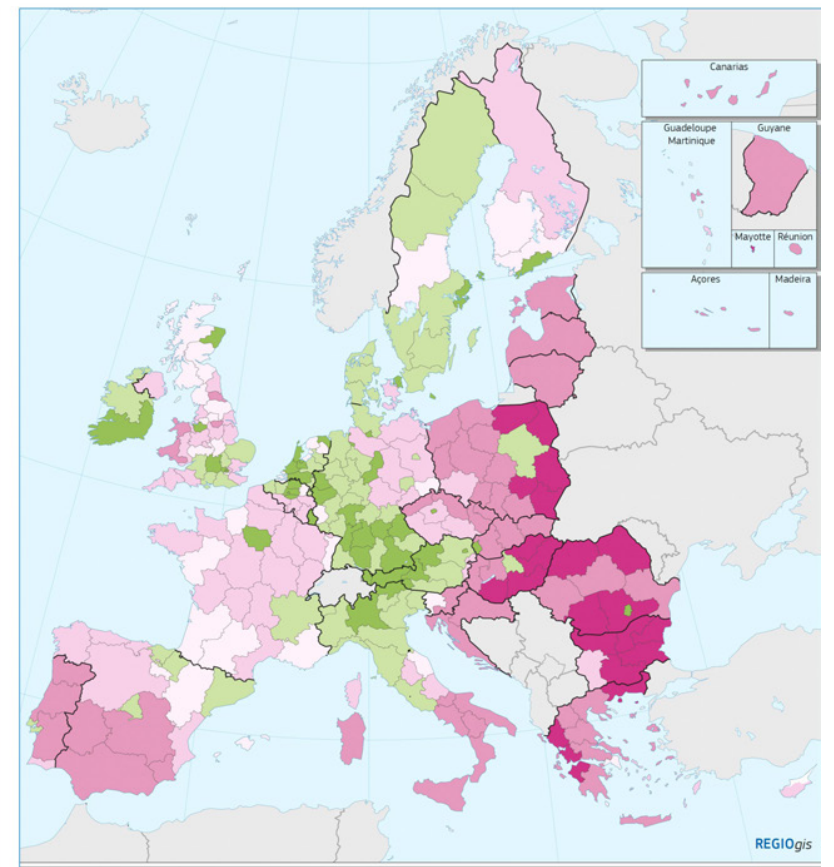

Map 1.1 GDP per head (PPS), 2015

Index, EU-28 = 100

450

$50-75$

$75-90$

$90-100$

$100-125$
$>=125$ 
Böhme, Doucet, Komornicki, Zaucha \& Świątek (2011, p. 52) came to the same conclusion in their study analysing the Europe 2020 strategy from a critical point of view:

One may also doubt whether the creation of new research jobs or an increase in the number

of patents can offer an answer to problems of all types of regions including those in rural

and sparsely populated or those that are structurally weak and therefore lagging behind.

When comparing two figures of the $3^{\text {rd }}$ and the $7^{\text {th }}$ Cohesion Reports representing the level of economic development of the European regions based on GDP per PPS in 2001 and 2015, one can conclude that the colours are different but the geographic patterns are almost the same (Fig. 1).

Globalisation and global competition have different effects in different regional contexts. When placing global competitiveness at the heart of Cohesion Policy, some regions will become the losers of the interventions even if they have a well-elaborated smart specialisation strategy. (Zonneveld \& Waterhout, 2005; EU, 2011)

Similarly, the strict monitoring rules ensuring (at least theoretically) the efficient utilisation of Cohesion Policy funding create 'one-size-fits-all' mechanisms disregarding the diverse conditions where they have to be applied. Thematic concentration (the EU's system of concentration of financial resources) is a principle which reminds us of the caricature of the competition where to guarantee equal opportunities, every animal has to climb the same tree: the monkey, the elephant, the fish and the bird, etc. 'Uniform indicators covering the entire EU territory usually fail to offer information about more complex regional differentiations.' (Böhme et al., 2011, p. 52).

In his dissertation, Stefan Telle (2018) analyses the above anomalies: the paradoxical duality of the Cohesion Policy mission which should ensure in parallel the EU's global competitiveness and the elimination of regional disparities. The first aspect requires concentration of resources to fields and issues where global competition is going on (thematic concentration). The second aspect necessitates the mitigation of differences between the European regions (strengthening of cohesion). Globalisation has 'unequal impacts on different parts of the EU' (Bachtler et al., 2017, p. 1) which means that regional settlement should not be handled along the same nomenclature (i.e. the system of indicators defined by thematic concentration).

In one of the most recent publications, Böhme, Lüer and Holstein (2020, p. 158) underline: Many of today's challenges and crises of the European Union can be traced back to neglecting a spatial dimension in policy-making. Most prominently, the current risk of territorial fragmentation is a result of places feeling discontent or left behind. (...) This is a result of the fact that there is an increasingly diverse 'European geography of future perspectives'. (...) different cities and regions face different everyday realities and their inhabitants see different future perspectives, not all of them hopeful ones.

What is more, if we compare the three key documents drafting EU development perspectives (namely Agenda 2000, the Lisbon Strategy and the EU2020 Strategy), we will see that territoriality plays a decreasing role therein. While Agenda 2000 was influenced by the spirit of the European Spatial Development Perspective (ESDP) which was elaborated in parallel with the former one, the Lisbon Strategy and the EU2020 Strategy instead concentrated on overall European goals of innovation, infrastructure and human capital development.

Bachtler et al. (2017) make recommendations how to reform Cohesion Policy, including differentiation in regional strategies 'designed with realism'; parallel development of human capacities with economic development; improvement of governance at local and regional level; and simplification of procedures. One can think that these recommendations are cited from the Barca Report (Barca, 2009) published almost ten years earlier. This means that the system (the paradigm) has not changed regardless of the numerous documents presenting concrete recommendations 
on how to make this shift (see e.g. Böhme et al., 2011; EU, 2011; Doucet, Böhme \& Zaucha, 2014; Medeiros, 2014, 2016; etc.). The main leitmotif - the need to protect Europe's global competitiveness - resulting in 'spatially/territorially blind' (Barca, 2009; Böhme et al., 2011; Doucet et al., 2014; Faludi, 2018) policies and strategies remained; even though territorial is the key factor among the three aspects of Cohesion Policy.

\section{How to interpret territorial cohesion}

According to professor Faudi, the term of territorial cohesion was embedded in the discourse on regional policy in 1995 by Robert Savy, vice-president of the Assembly of European Regions (AER). Thanks to his lobbying, territorial cohesion was incorporated in the text of the Treaty of Amsterdam $^{2}$ in 1997 (Faludi, 2009, p. 2). Ten years later, with the concept of Cohesion Policy, inclusive of its territorial aspect in the Treaty of Lisbon, Commissioner for Regional Policy, Danuta Hübner insisted on a 'clear and common understanding of the concept' (quoted by Abrahams, 2014, p. 2135). However, this definition still does not exist (see e.g. Faludi, 2013; Doucet et al., 2014; Medeiros, 2016).

The idea of creating a framework for European spatial planning was born in 1970, when the Council of Europe established the European Conference of Ministers responsible for Spatial Planning (CEMAT; Conférence Européenne des Ministres responsables de l'Aménagement du Territoire). In 1983, the Conference adopted the so-called Torremolinos Charter (COE, 1983) setting the roadmap for a common European territorial policy to ensure harmonious economic and social development of the Continent. The ministers started developing a European spatial planning strategy as well, but, because of financial problems, the Council of Europe had to limit the activities of CEMAT (Faludi, 2009, p. 9). Consequently, the French and Dutch ministers decided to establish a similar network at Community level. In 1989, the relevant representatives of the member countries of the EEC informally met in Nantes. This was the first step towards the adoption of the ESDP which was an encyclopedic summary and analysis of the territorial development processes and perspectives of the Communities, including recommendations on necessary coordination of spatial planning (EC, 1999). The document is seen as the most important milestone of the 'canonisation' of territoriality in Cohesion Policy which has been used as a reference point when drafting subsequent documents.

Since that time, the types of papers aiming to define territorial cohesion can be grouped into three:

a) legal documents issued by the European institutions ruling Cohesion Policy, i.e. the Treaties and Cohesion Policy Regulations;

b) documents drafted by professionals of spatial planning and territorial policies, partly adopted by the ministers responsible for spatial planning (may be named as 'debate papers'), from the Territorial State and Perspectives of the European Union (TSP) to the Territorial Agenda 2030 titled Future for all places, including the Cohesion Reports;

c) ESPON projects analysing the topic, especially the projects 3.2 (Spatial Scenarios and Orientations in relation to the ESDP and Cohesion Policy), INTERCO (Indicators of Territorial Cohesion) and KITCASP (Key Indicators for Territorial Cohesion and Spatial Planning). These documents have different focuses and give an interpretation horizon of the term, even if they do not provide a final definition.

\footnotetext{
2 See EU (1997).
} 
Table 1. Changing thematic focuses of Cohesion Policy documents since 1999

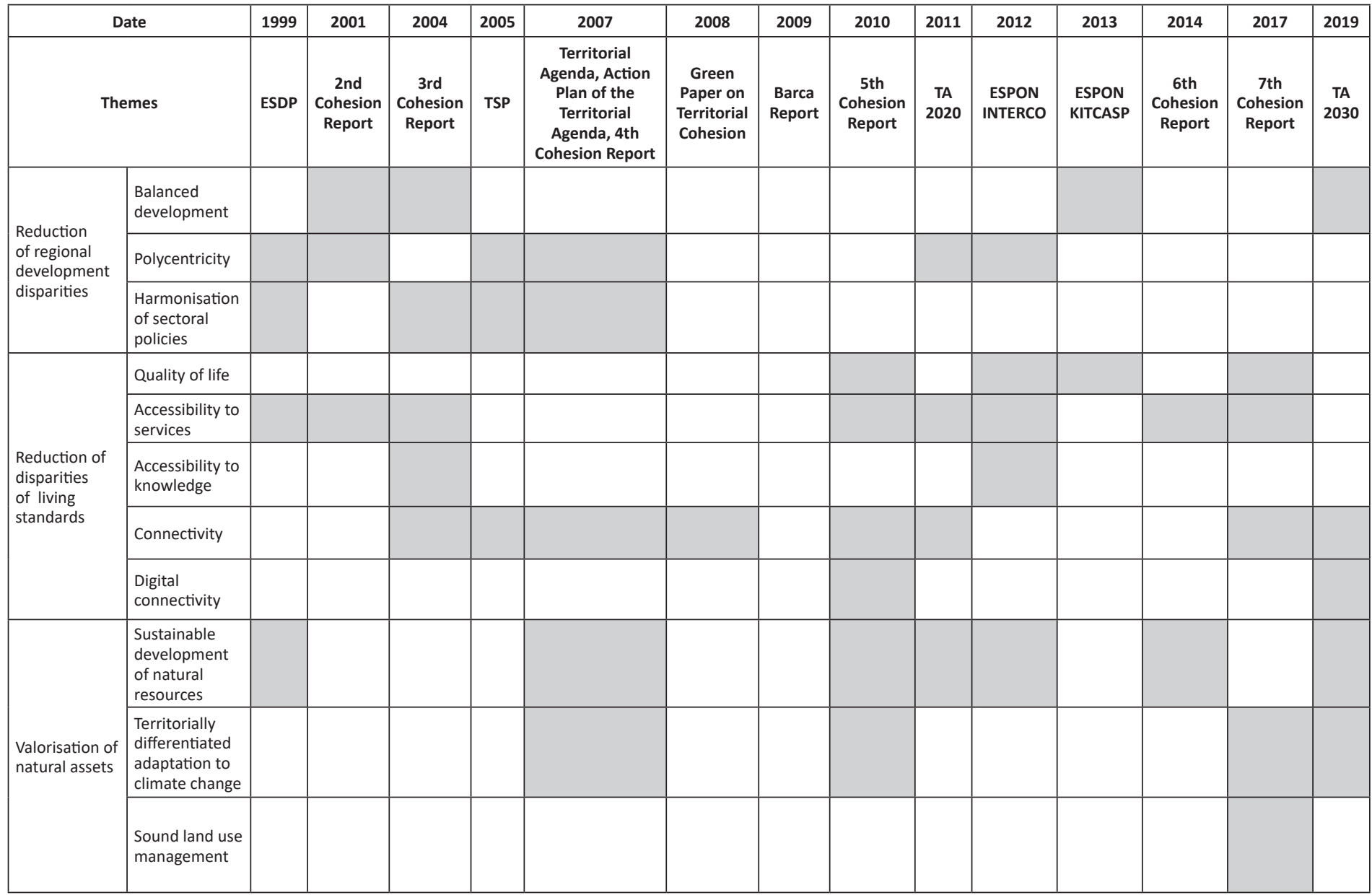




\begin{tabular}{|c|c|c|c|c|c|c|c|c|c|c|c|c|c|c|c|}
\hline & ate & 1999 & 2001 & 2004 & 2005 & 2007 & 2008 & 2009 & 2010 & 2011 & 2012 & 2013 & 2014 & 2017 & 2019 \\
\hline & mes & ESDP & $\begin{array}{l}\text { 2nd } \\
\text { Cohesion }\end{array}$ & $\begin{array}{c}\text { 3rd } \\
\text { Cohesion }\end{array}$ & TSP & $\begin{array}{l}\text { Territorial } \\
\text { Agenda, Action } \\
\text { Plan of the } \\
\text { Territorial }\end{array}$ & $\begin{array}{l}\text { Green } \\
\text { Paper on } \\
\text { Territorial }\end{array}$ & $\begin{array}{l}\text { Barca } \\
\text { Report }\end{array}$ & $\begin{array}{c}\text { 5th } \\
\text { Cohesion }\end{array}$ & $\begin{array}{c}\text { TA } \\
2020\end{array}$ & $\begin{array}{c}\text { ESPON } \\
\text { INTERCO }\end{array}$ & $\begin{array}{l}\text { ESPON } \\
\text { KITCASP }\end{array}$ & $\begin{array}{c}\text { 6th } \\
\text { Cohesion }\end{array}$ & $\begin{array}{c}\text { 7th } \\
\text { Cohesion }\end{array}$ & $\begin{array}{c}\text { TA } \\
2030\end{array}$ \\
\hline $\begin{array}{l}\text { Management } \\
\text { of } \\
\text { environmental } \\
\text { resources }\end{array}$ & $\begin{array}{l}\text { Environment } \\
\text { management }\end{array}$ & & & & & & & & & & & & & & \\
\hline & $\begin{array}{l}\text { Developmen } \\
\text { promoting } \\
\text { diversity }\end{array}$ & & & & & & & & & & & & & & \\
\hline & $\begin{array}{l}\text { Territorial } \\
\text { capital }\end{array}$ & & & & & & & & & & & & & & \\
\hline $\begin{array}{c}\text { of } \\
\text { endogenous }\end{array}$ & $\begin{array}{l}\text { Place-based } \\
\text { approach }\end{array}$ & & & & & & & & & & & & & & \\
\hline & $\begin{array}{l}\text { Functional } \\
\text { regions }\end{array}$ & & & & & & & & & & & & & & \\
\hline & $\begin{array}{l}\text { Territorial } \\
\text { integration }\end{array}$ & & & & & & & & & & & & & & \\
\hline & $\begin{array}{l}\text { Urban-rural } \\
\text { partnership }\end{array}$ & & & & & & & & & & & & & & \\
\hline Governance & $\begin{array}{l}\text { Multi-level } \\
\text { governance }\end{array}$ & & & & & & & & & & & & & & \\
\hline & Subsidiarity & & & & & & & & & & & & & & \\
\hline & $\begin{array}{l}\text { Territorial } \\
\text { cooperation }\end{array}$ & & & & & & & & & & & & & & \\
\hline
\end{tabular}

Source: authors' own elaboration based on Barca (2009), EC (2001, 2007, 2008, 2010, 2014), ESPON (2012, 2013) and EU (2005, 2007a, 2007b, 2011, 2020). 
Table 1 shows how the different highlighted aspects of territorial cohesion varied over the past decades ${ }^{3}$. There are components which can be considered more or less permanent, such as sustainable management of natural resources, equal access to services, the development of transport connections and territorial cooperation. Others have lost their central role, e.g. harmonisation of sectoral policies (replaced by territorially integrated interventions); urban-rural partnership (replaced by governance and institutional issues) or polycentric urban networks (replaced by sustainable cities). Those approaches focusing on endogenous assets and uniqueness of the regions appeared in the mid-2000s in parallel with the growing popularity of endogenous growth theories in global economics (Capello, 2009). The Barca Report (Barca, 2009) was the most important milestone in this progress. However, as we have seen, the Report itself could not bring about a paradigm shift. The reason was that the interpretative change insisted on by Fabrizio Barca has not been performed at EU policy level. As territorial development is a competence of the Member States, the Union cannot do anything else but provide different tools (such as integrated territorial investment - ITI); community-led local development - CLLD based on the LEADER methodology; or, most recently, the concept of functional areas) which prioritise the territorial approach in the implementation of programmes. At the same time, the system of thematic concentration and compulsory indicators, matching of the need for global competitiveness; the complicated monitoring procedures; and the hard-to-understand State Aid regime paralyse the realisation of territorially-designed interventions. Despite the availability of territorial tools, the territorial dimension of the interventions is very weak, - ultimately endangering the preservation of the EU's global competitiveness. A chain is never stronger than its weakest link: a fact of particular importance to territorial cohesion.

\section{The great challenge of territoriality}

When analysing the interpretation horizon of territorial cohesion, one can differentiate two major trends represented in Table 1. On the one hand, territorial cohesion is still approached from the point of view of convergence. Cohesion Reports give us a comprehensive picture of how changes of economic and social cohesion can be detected region by region. This approach concentrates on regional disparities and considers territorial cohesion as a mere horizontal factor of economic and social cohesion. However, when analysing the productivity of a given sector at regional level, we do not say anything about territorial cohesion. Instead, this approach touches upon the territorial aspects of economic cohesion. When describing the phenomena of unemployment by regions, we remain within the confines of social cohesion, discussing it from a spatial perspective. Subsequently, this approach does not enable us to define territorial cohesion.

On the other hand, experts often analyse territorial specificities and endowments, such as climate change vulnerability, energy production and consumption, land use management, air quality, etc. These phenomena always have territorial aspects but what do we mean by territorial cohesion here? What is the consequence for territorial cohesion if one particular region's vulnerability is higher than another's? If the rate of dwellings equipped with a sewage system in a region is $85 \%$ while in another it is $72 \%$, what can we learn from these figures about territorial cohesion?

Apparently, both approaches represent dead ends.

The cause of this first (negative) conclusion is the failed interpretation of 'territoriality'. The concept cannot be separated from borders which are, indeed, 'expressions of territoriality' (Paasi,

\footnotetext{
${ }^{3}$ Similar table is included in Medeiros (2016).
} 
2011, p. 22). Several scholars (e.g. van Houtum, 1998, 2003; O’Dowd, 2003; Faludi, 2012; Popescu, 2012) quote Sack's (1986, p. 19) following definition of the notion: 'the attempt by an individual or group to affect, influence or control people and/or phenomena, by delimiting and asserting control over a geographical area'. The even symbolic enclosure of geographic space creates territory. There are no unbounded territories. The control over a given territory becomes visible by delimitation and demarcation (Popescu, 2012). Delimitation and demarcation always mean a zero-sum game: a certain geographic unit cannot belong but to one authority which limits the access for other authorities thereto (Anderson, O'Dowd \& Wilson, 2003; van Houtum, 2003; Faludi, 2018). To put it differently: sovereignty of one authority over a territory excludes the sovereignty of others. As a product of modernity, this sovereignty is exercised by bureaucratic nation states. 'Nations are the institutionalisation of a territory', claims van Houtum in his dissertation (van Houtum, 1998, p. 28).

At the same time, the EU has no territory. When a refugee or an American businessman arrives in the EU they have to register themselves with the authority of a particular country. It is true that after that (in normal periods) they can move without limitations inside the Schengen zone, but they are allowed to do this based on the agreement of sovereign countries. As the share of a geographic space to territories is a zero-sum game, the EU cannot exercise its authority over the territory of its Member States. It is not incidental that nation states do not show intention to abandon their competencies over territorial development policies.

What does European territorial cohesion mean if the EU has no territory but there are the Member States who do have? If Member States have territories, what does their cohesion mean? How can we overcome this definition difficulty?

As we can see, within the framework of the current paradigm we face a proliferating number of anomalies: regional disparities do not decrease; the goals related to the preservation of European global competitiveness are in conflict with territorial needs; thematic concentration paralyses integrated regional interventions, which increases the differences between the regions; there is no clear definition of European territorial cohesion because the EU has no territory... From this point of view, European Cohesion Policy shows the sign of a systemic error.

Kuhn's paradigm theory is often criticised by citing the rare examples of scientific revolutions when the worldview has changed. The examples mentioned the most are the shift from the geocentric worldview to the heliocentric one and the publication of Einstein's theory of relativity. If we consider the above system error, it is worth approaching the phenomenon from the opposite side, from outside the current paradigm.

\section{The paradigm shift: the logic of the brick wall}

Currently, there are three potential responses to the challenge that the above definition problem is built upon. Each of them necessitates a paradigm shift in European thinking, with a special focus on so-called 'territoriality'.

First, the question of territorial cohesion can be answered if the EU has its own territory (neofunctionalist approach). It means that the EU replaces nation states and becomes a kind of new 'nation state' - as for instance Jürgen Habermas (2012, p. 348) urges. One of the greatest German philosophers of the last 100 years envisions the development of the 'first transnational democracy (...) exercising a kind of post-democratic rule' based on civil solidarity reaching beyond national borders. The new entity would not be a genuine nation state because its sovereignty would rest upon the Member States on the one hand, and the European citizens (directly), on the other. 
In our opinion, for the purpose of achieving the ownership of a territory, further integration of the Union is needed where nation states lose their sovereignty. Shared competencies perpetuate conflicts of interest between different level authorities. Even if the disappearance of the nation states is improbable in the foreseeable future, this option would guarantee the sovereignty of the Community over the 'European territory' and the application of territorial cohesion at EU level.

However, there are several arguments opposing this option. On the one hand, the vision of transnational democracy cannot stop at the EU's external borders. Otherwise, the model has to exclude those remaining outside the EU - which contradicts the core assumptions of the concept. Habermas shares this view. In his opinion, the European integration is 'an important step on the path towards a politically constituted world society' (Habermas, 2012, p. 336). Obviously, this broadened horizon makes territoriality unintelligible at EU level.

On the other hand, this option extends beyond the traditional concept of democracy. As Faludi (2018) and Telle (2018) highlight: the European demos does not exist. Without demos, there is no democracy. As one of the founders of modern liberalism, John Stuart Mill put it in 1861 (2001, p. 184): 'it is in general a necessary condition of free institutions that the boundaries of governments should coincide in the main with those of nationalities'. Since then, it has been a common belief that nothing other than national institutions can guarantee the effectuation of democratic rights. Upon terminating the operation of national institutions, citizens lose their chance to influence decisions (see e.g. Furedi, 2021). Dani Rodrik calls this phenomenon 'the globalization paradox', based on Obstfeld and Taylor's economic trilemma and Thomas Friedman's dilemma. According to Rodrik's trilemma, it is impossible to ensure the effectiveness of the three factors of nation state, hyperglobalization (earlier: integrated national economies), national self-determination and democratic politics (earlier: mass politics) simultaneously (Rodrik, 2000, 2011). In each case of the combination of two of the three, the third must be excluded:

We can restrict democracy in the interest of minimizing international transaction costs

(...) We can limit globalization, in the hope of building democratic legitimacy at home.

Or we can globalize democracy, at the cost of national sovereignty. (...) [W] cannot have

hyperglobalization, democracy, and national self-determination all at once. (Rodrik, 2011,

p. 200 - emphasis in the original).

Finally, once surrendering national sovereignty, we have to accept the consolidation of the 'preeminence of the economically more powerful countries' at the global democratic scene (Rodrik, 2000, p. 185). Besides, taking into account the complexity of the logistics of voting and the diversity of opinions in such a broad community, this new form of governance would be more a way of management than of interest representation, (Telle, 2018, p. 96).

The second option is called 'neo-medievalism'. The most popular representative of this thinking is Jan Zielonka. In his opinion, in contrast to the 'Westphalian statism' ruling the last centuries, the EU follows the logic of an empire (Zielonka, 2006, p. 167):

The existing body of evidence leaves little doubt that the enlarged EU cannot become a

Westphalian superstate. The Union is on its way to becoming a neo-medieval empire with soft borders in flux, cascading socio-economic discrepancies, multiple cultural identities, and a polycentric government.

The neo-medieval model features permanent fragmentation both in terms of politics and geography. Zielonka does not expect that the European Parliament will become the main decision-making body of the federal European state: 'The public space in the enlarged EU is likely to remain fragmented and weak preventing the rise of a single and dominant European identity, ethos, and demos.' (2006, p. 169). In his latest publication, Andreas Faludi pursues this line of thought on di- 
vided sovereignty when forecasting the emergence of a 'multitude of overlapping relative spaces' (Faludi, 2018, p. 131). For him, 'European space is not a container, as if it were a (federal) state, but a cloud of formation' p. 135).

According to this model, territorial cohesion requires the identification of 'ad hoc, tailor-made, and thus varied, overlapping territories' (Faludi, 2018, p. 166). To put it differently, this paradigm shift means the re-interpretation of 'old terms': territory is not territory anymore in its sense connected to the sovereignty principle. It is rather about social contacts changing in time matched with diverse settings of power in a neo-medieval manner.

Yet, at the level of perception, today's people live in a fundamentally different world than that of the Middle Ages. It is true that the universalistic identity narrative of the nation state (complying with the rationalism of modernity) is no longer the monopolistic worldview. Its totalising discourse has weakened (as a consequence of challenges like climate change, global market development, migration, pandemics, etc.) and numerous local discourses are born similarly to medieval Europe. At the same time, the revolutions of transport and communication have radically extended the frames of our spatial orientation shedding a brand new light on locality (locus) and territoriality. While medieval subjects of the king received their spatial narratives defining their local-regional identity ready-made, the identity of the postmodern people is permanently fluctuating between different discourses of space made by different (groups of) agents. National narrative is just one among them. Therefore, the meaning of territoriality in the age of the internet gains a rather vague character which does not make easier to define territorial cohesion.

The third option of 'experimentalist governance' is close to this second one when asserting the pluralistic nature of spatial structures. Stefan Telle agrees with Faludi in that 'regions should be analyzed as social constructs' (Telle, 2018, p. 55). This social factor creates soft spaces from territories.

[Soft spaces] involve the creation of new geographies that transcend existing political administrative boundaries. As such, they represent specific social constructions of space that do not correspond to the political-territorial boundaries and internal divisions of the nation state. (Allmendinger, Haughton, Knieling \& Othengrafen, 2015, p. 4).

This approach goes beyond the democratic dilemma: “(...) soft spaces may also operate as post-political spaces that 'work behind' territorial spaces, providing strategies and policies" (Allmendinger et al., p. 13).

Telle (2018, p. 97) contrasts 'modernist' regional policy concentrating on equality with 'postmodern' cohesion policy emphasising 'freedom'. Here, spatiality replaces territoriality.

Instead of bounded reality, soft spaces have a fuzzy character with changing delimitations and demarcations over time. It means that soft spaces are created and re-created (re-scaled) in an experimental way, very often independently from national or EU level agendas. This creative attitude to spatial development has very strong stimulating power offering an impetus to backward areas.

This last approach enables us to define the essence of the proposed paradigm shift in European Regional Policy, which we compare to a brick wall. When Copernicus devised the heliocentric model, he turned (meta)physics upside down. We should follow this Copernican turn. Up to now, Cohesion Policy has been determined by a top-down logic - regardless of the heroic attempts made by the protagonists of locality, territorial capital and the space-based approach. The need for the preservation of global competitiveness made it necessary to set the objectives at the level of the EU. Regional and local actors (who cannot directly participate in the design of the Cohesion Policy Regulations) had to match their spatial needs with the system 'ready-cooked'; including the thematic (most recently: policy) objectives, specific objectives, types of interventions and the indi- 
cators (briefly: the intervention logic of Cohesion Policy). The house of Europe is built from the roof to the base. For local stakeholders it has always been clear that this method of construction cannot be effective since they have to hold the roof until bricklayers build the walls...

Instead, European Cohesion should be built up brick by brick, each well bonded to the other. According to this model, competitiveness rests upon local energies and global interconnectedness. In the age of global communication, localities are appraised - often independently from or despite EU policy objectives - for how specifically they can add directly to global prosperity. How does this experimental approach impact the definition of territorial cohesion? First, we should finally forget convergence. The capital cities and metropolitan areas of less developed countries are catching up, but partly due to the divergent development of urban and rural policy (and the separated funding and rules) the effects of this catching up process cannot be detected in more remote areas. Second, the place-based philosophy of the Barca Report and the territorial capital school should be taken seriously. When defining common European targets at the global level, those regions are prioritised which are better equipped with capacities relevant in the global competition while others will keep lagging behind. Instead, the very local/regional capacities should be promoted, local initiatives and dialogues should be incentivised and the funds should support implementation strategies built upon territorial capital of the given region. Third, the term of territoriality should be replaced by spatiality: so reaching beyond the nation-state confines.

The recent pandemic showed us that locality and regionality can have a special added value based on non-reproducible local knowledge and social capital (even over the administrative boundaries) that represents a potential worth exploiting. Spatial cohesion can create new innovative ties and solutions and give a new impetus to local, national and European growth. Investing more on locality and allowing for softer policy design involving local stakeholders would mean a paradigm shift. Instead of thematic concentration, the EU needs spatial concentration and competition between regions as engines of global competition.

\section{Conclusion}

In this article, we adapted Kuhn's theory on scientific revolutions to an explanation of the current crises of the EU. In our view, global competitiveness of the EU is endangered by the erroneous top-down logic of Cohesion Policy. On the one hand, in line with the current paradigm, the interventions of Cohesion Policy are determined at EU level. At the same time, regional re-distribution has not been able to yield results so far: regional disparities have been increasing. On the other hand, the development strategies and policies of the EU are territorially blind: the objectives and intervention logic of these strategies and programmes concentrate on pan-European goals to which local and regional actors have to adhere regardless of their capacities and special (spatial) endowments. Numerous experts and academics have highlighted that this approach is not effective. As a consequence, the Commission proposed territorial tools such as ITI, CLLD and it now promotes the development of functional areas. However, when designing territorially integrated interventions, local actors always confront the system of indicators, specific objectives and overcomplicated implementation and monitoring rules, thus making the realisation of these interventions too costly to try.

A further anomaly of the current system is an incorrect interpretation of territorial cohesion. Taking into account that territoriality is inseparable from the nation state sovereignty; the EU does not have its own territory. Hence, apart from the missing definition of territorial cohesion, even territoriality is hardly interpretable at EU level. 
This article presents three options expanding the frames of the above anomalies of the current paradigm: the 'neofunctionalist' which foresees further progress of supranational integration creating the conditions for the emergence of the European territory; the 'neo-medievalist' which rather finds the future of the Continent in the development of overlapping territories governed by overlapping authorities; and the 'experimentalist' abandoning the territorial concept and replacing it with a spatial perspective where European development perspectives are built up brick by brick, i.e. from local to regional, national and Community level policies.

Kuhn stated that once the quantity of anomalies reaches the critical point, the scientific revolution creates the conditions for a new paradigm, a new matrix or a new vocabulary. The new paradigm should be incommensurable with the old one: even if the terms are the same, their meanings are changed. In this way, paradigm shift creates a new discourse and a new institutional set of power relationships, a new reality. For sure, it is exaggerating to assert that our proposal represents a paradigm shift. But perhaps we are just too 'cowardly' to try it...

\section{References}

Abrahams, G. (2014). What "Is" Territorial Cohesion? What Does It "Do"?: Essentialist Versus Pragmatic Approaches to Using Concepts. European Planning Studies, 22(10), 2134-2155. https://doi.org/10.1 080/09654313.2013.819838

Allmendinger, P., Haughton, G., Knieling, J., \& Othengrafen, F. (2015). Soft spaces, planning and emerging practices of territorial governance. In P., Allmendinger, G., Haughton, J., Knieling \& F., Othengrafen (Eds.). Soft Spaces in Europe. Re-negotiating governance, boundaries and borders (pp. 3-22). London-New York, NY: Routledge.

Anderson, J., O'Dowd, L., \& Wilson, T. M. (2003). Why Study Borders Now? In J., Anderson, L., O'Dowd, \& T. M., Wilson (Eds.). New Borders for a Changing Europe. Cross-Border Cooperation and Governance (pp. 1-12). London-New York, NY: Routledge Taylor and Francis Group.

Bachtler, J., Martins, J.O., Wostner, P., \& Żuber, P. (2017). Towards Cohesion Policy 4.0. Structural transformation and inclusive growth. Working Paper. Brussels: Regional Studies Association.

Barca, F. (2009). An agenda for a reformed Cohesion Policy. A place-based approach to meeting European Union challenges and expectations. Retrieved from https://ec.europa.eu/regional_policy/ archive/policy/future/pdf/report_barca_v0306.pdf

Bell, C. (2009). Ritual, Theory, Ritual Practice. Oxford: Oxford University Press.

Böhme, K., Doucet, P., Komornicki, T., Zaucha, J., \& Świątek, D. (2011). How to strengthen the territorial dimension of "Europe 2020" and EU Cohesion Policy. Warsaw.

Böhme, K., Lüer, C., \& Holstein, F. (2020). From Territorial Impact Assessment to Territorial Foresight. In E., Medeiros (Ed.). Territorial Impact Assessment (pp. 157-176). Cham: Springer.

Capello, R. (2009). Space, growth and development. In R., Capello \& P., Nijkamp (Ed.). Handbook of Regional Growth and Development Theories (pp. 33-52). Cheltenham-Northampton, MA: Edward Elgar.

CESCI (2015). For a more place-based approach. Position paper of CESCl on the Future of Cohesion Policy. Retrieved from https://budapest.cesci-net.eu/en/for-a-more-place-based-approach-positionpaper-of-cesci-on-the-future-of-cohesion-policy/

COE (1983). Resolution no. 2 on the European Regional/Spatial Planning Charter (Torremolinos Charter). Council of Europe. Agreed at the European Conference of Ministers responsible for Regional Planning (CEMAT). Retrieved from https://rm.coe.int/6th-european-conference-of-ministers-responsible-for-regional-planning/168076dd93

Doucet, P., Böhme, K., \& Zaucha, J. (2014). EU territory and policy-making: from words to deeds to promote policy integration. European Journal of Spatial Development.

EC (1957). The Treaty of Rome 25 March 1957. Retrieved from https://ec.europa.eu/romania/sites/romania/files/tratatul_de_la_roma.pdf 
EC (1987). Single European Act. 17 February 1986, 1987 O.J. (L 169) 1, 25 I.L.M. 506.

EC (1999). ESDP. European Spatial Development Perspective. Towards Balanced and Sustainable Development of the Territory of the European Union. Luxembourg: European Commission.

EC (2001). Second Report on Economic and Social Cohesion. Retrieved from https://ec.europa.eu/regional_policy/sources/docoffic/official/reports/pdf/conclu1_en.pdf

EC (2004). A new partnership for cohesion. Convergence, competitiveness, cooperation. Third report on economic and social cohesion. Luxemburg: European Communities.

EC (2007). Growing regions, Growing Europe. Fourth Report on Economic and Social Cohesion. Luxembourg: European Commission. Retrieved from https://ec.europa.eu/regional_policy/sources/docoffic/official/reports/cohesion4/index_en.htm

EC (2008). Communication from the Commission to the Council, the European Parliament, the Committee of the regions and the European Economic and Social Committee. Green Paper on Territorial Cohesion Turning territorial diversity into strength. COM(2008) 616 final. Retrieved from https:// eur-lex.europa.eu/LexUriServ/LexUriServ.do?uri=COM:2008:0616:FIN:EN:PDF

EC (2010). Investing in Europe's future. Fifth report on economic, social and territorial cohesion. European Commission. Retrieved from https://ec.europa.eu/regional_policy/en/information/publications/ reports/2010/fifth-report-on-economic-social-and-territorial-cohesion-investing-in-europe-s-future

EC (2014). Investment for jobs and growth. Promoting development and good governance in EU regions and cities. Sixth report on economic, social and territorial cohesion. Luxembourg: European Commission. Retrieved from https://ec.europa.eu/regional_policy/en/information/publications/ reports/2014/6th-report-on-economic-social-and-territorial-cohesion

EC (2017). My Region, My Europe, Our Future. Seventh report on economic, social and territorial cohesion. Luxembourg: European Commission. Retrieved from https://ec.europa.eu/regional_policy/en/ information/cohesion-report/

ESPON (2012). INTERCO. Indicators of territorial cohesion. Scientific Platform and Tools Project 2013/3/2. Final Report, Part B, Report. Retrieved from https://www.espon.eu/programme/projects/ espon-2013/scientific-platform/interco-indicators-territorial-cohesion

ESPON (2013). KITCASP. Key Indicators for Territorial Cohesion and Spatial Planning. Targeted Analysis 2013/2/20. Final Report. Part B, Main Report. Retrieved from https://www.espon.eu/programme/ projects/espon-2013/targeted-analyses/kitcasp-key-indicators-territorial-cohesion-and

EU (1992). Treaty on European Union (Consolidated Version), Treaty of Maastricht. 7 February 1992, Official Journal of the European Communities C 325/5.

EU (1997). Treaty on European Union (Consolidated Version), Treaty of Amsterdam. 2 October 1997. Retrieved from https://europa.eu/european-union/sites/europaeu/files/docs/body/treaty_of_amsterdam_en.pdf

EU (2005). The Territorial State and Perspectives of the European Union Document. Towards a Stronger European Territorial Cohesion in the Light of the Lisbon and Gothenburg Ambitions. Retrieved from https://www.ccre.org/docs/territorial_state_and_perspectives.pdf

EU (2007a). Territorial Agenda of the European Union. Towards a More Competitive and Sustainable Europe of Diverse Regions. Retrieved from https://ec.europa.eu/regional_policy/sources/policy/what/ territorial-cohesion/territorial_agenda_leipzig2007.pdf

EU (2007b). First Action Programme for the Implementation of the Territorial Agenda of the European Union. Retrieved from https://ec.europa.eu/regional_policy/sources/policy/what/territorial-cohesion/territorial_agenda_first_action_plan.pdf

EU (2011). Territorial Agenda of the European Union 2020. Towards an Inclusive, Smart and Sustainable Europe of Diverse Regions. Retrieved from https://ec.europa.eu/regional_policy/sources/policy/ what/territorial-cohesion/territorial_agenda_2020.pdf

EU (2012). Consolidated versions of the Treaty on European Union and the Treaty on the Functioning of the European Union - Consolidated version of the Treaty on the Functioning of the European Union - Protocols - Annexes - Declarations annexed to the Final Act of the Intergovernmental Conference which adopted the Treaty of Lisbon, signed on 13 December 2007. OJ C 326, 26/10/2012 P. 00010390. Retrieved from https://eur-lex.europa.eu/legal-content/EN/TXT/HTML/?uri=CELEX:12012E/ TXT\&from=EN 
EU (2020). Territorial Agenda. A future for all places. Retrieved from https://www.territorialagenda. eu/files/agenda_theme/agenda_data/Territorial\%20Agenda\%20documents/TerritorialAgenda2030_201201.pdf

Evans, D. (1996). An Introductory Dictionary of Lacanian Psychoanalysis. London: Routledge.

Faludi, A. (2009). Territorial Cohesion under the Looking Glass. Synthesis paper about the history of the concept and policy background to territorial cohesion. Brussels: European Commission. Retrieved from http://resolver.tudelft.nl/uuid:112891b3-3dd6-4252-b0a5-452e5665f0d9

Faludi, A. (2012). Beyond Lisbon: Soft European Spatial Planning. disP - The Planning Review, 46(182), 14-24. https://doi.org/10.1080/02513625.2010.10557098

Faludi, A. (2013). Territory: An Unknown Quantity in Debates on Territorial Cohesion. European Journal of Spatial Development, 51.

Faludi, A. (2018). The Poverty of Territorialism. A Neo-Medieval View of Europe and European Planning. Cheltenham-Northampton MA: Edward Elgar.

Foucault, M. (1966/2002). The Order of Things: An archaeology of the human sciences. London-New York, NY: Routledge.

Foucault, M. (1972/1980). Power/knowledge: Selected Interviews and Other Writings 1972-1977. New York, NY: Pantheon Books.

Foucault, M. (1978). Discipline and Punish: The Birth of the Prison. New York, NY: Vintage Books.

Furedi, F. (2021). Why Borders Matter: Why Humanity Must Relearn the Art of Drawing Boundaries. London, New York, NY: Routledge, Taylor \& Francis Group.

Gregory, D. (2004). The Colonial Present. Malden, MA: Blackwell.

Habermas, J. (2012). The Crisis of the European Union in the Light of a Constitutionalization of International Law. The European Journal of International Law, 23(2), 335-348. https://doi.org/10.1093/ejil/ chs019

Hacking, I. (2012). Introductory Essay. In T., Kuhn (Ed.). The Structure of Scientific Revolutions (pp. vii-xiv). Chicago-London: The University of Chicago Press.

Harvey, D. (2011). The Enigma of Capital: And the Crises of Capitalism. London: Verso.

Kuhn, S. T. (1962/1970). The Structure of Scientific Revolutions. Chicago, IL: The University of Chicago Press.

Kuhn, S.T. (1962/1970/1996/2012). The Structure of Scientific Revolutions. Chicago, IL: The University of Chicago Press.

Laclau, E. (2007). Emancipation(s). London: Verso.

March, G. J. (1991). Exploration and Exploitation in Organizational Learning. Organization Science, 2(1), 71-87.

McCarthy, T. (2009). Race, Empire, and the Idea of Human development. Cambridge, MA: Cambridge University Press.

Medeiros, E. (2014). Assessing Territorial Impacts of the EU Cohesion Policy at the Regional Level: the Case of Algarve. Impact Assessment and Project Appraisal, 32(3), 198-212. https://doi.org/10.10 80/14615517.2014.915134

Medeiros, E. (2016). Territorial Cohesion: An EU concept. European Journal of Spatial Development, 60. Mill, J. S. (2001). Representative Government 1861. Kitchener: Batoche Books.

Neumann, I. (2013). Diplomatic Sites: A Critical Enquiry. Oxford: Oxford University Press.

O'Dowd, L. (2003). The Changing Significance of European Borders. In J., Anderson, L., O'Dowd \& T. M., Wilson (Eds.). New Borders for a Changing Europe. Cross-Border Cooperation and Governance (pp. 13-36). London-New York, NY: Routledge Taylor and Francis Group.

Olsen, P. J. (2010). Governing through Institution Building: Institutional Theory and Recent European Experiments in Democratic Organization. Oxford-New York, NY: University Press.

Paasi, A. (2011). A "Border theory": an unattainable dream or a realistic aim for border scholars? In D., Wastl-Walter (Ed.). Companion to border studies (pp. 11-31). Farnham: Ashgate.

Popescu, G. (2012). Bordering and Ordering the Twenty-first Century. Understanding Borders. LanhamBoulder-New York-Toronto-Plymouth: Rowman \& Littlefield Publishers.

Rechnitzer, J., \& Smahó, M. (2011). Területi politika. Budapest: Akadémiai Kiadó. 
Reitel, B., Wassenberg, B., \& Peyrony, J. (2018). The INTERREG Experience in Bridging European Territories. A 30-Year Summary. In E., Medeiros (Ed.). European Territorial Cooperation. Theoretical and Empirical Approaches to the Process and Impacts of Cross-Border and Transnational Cooperation in Europe (pp. 7-23). Cham: Springer.

Rodrik, D. (2000). How Far Will International Economic Integration Go? Journal of Economic Perspectives, 14(1), 177-186. https://doi.org/10.1257/jep.14.1.177

Rodrik, D. (2011). The Globalization Paradox. Democracy and the Future of the World Economy. OxfordNew York, NY: Oxford University Press.

Sack, R. D. (1986). Human Territoriality: Its Theory and History. Cambridge: Cambridge University Press.

Shakespeare, W. (1599-1602/1999) The Tragedy of Hamlet, Prince of Denmark. Retrieved from https:// www.w3.org/People/maxf/XSLideMaker/hamlet.pdf

Stinchombe, A. (1987). Constructing Social Theories. Chicago, IL: University of Chicago Press.

Svensson, S., \& Balogh, P. (2018). Limits to Integration: Persisting Border Obstacles in the EU. In E., Medeiros (Ed.). European Territorial Cooperation. Theoretical and Empirical Approaches to the Process and Impacts of Cross-Border and Transnational Cooperation in Europe (pp. 115-134). Cham: Springer.

Taylor, D. (2011). Michel Foucault: Key Concepts. Durham: Acumen.

Telle, S. (2018). The 'Added Value' of Soft Spaces to EU Cohesion Policy Comparing Cross-Border Cooperation in Two Central European Euroregions. Dissertation. Retrieved from https://www.researchgate. net/publication/325596113_The_'Added_Value'_of_Soft_Spaces_to_EU_Cohesion_Policy_Comparing_Cross-Border_Cooperation_in_Two_Central_European_Euroregions

van Houtum, H. (1998). The Development of Cross-Border Economic Relations. Amsterdam: ThelaThesis Publishers.

van Houtum, H. (2003). Borders of Comfort: Spatial Economic Bordering Processes in the European Union. In J., Anderson, L., O’Dowd \&T. M., Wilson (Eds.). New Borders for a Changing Europe. Cross-Border Cooperation and Governance (pp. 37-58). London-New York, NY: Routledge Taylor and Francis Group.

Veggeland, N. (2004). Post-national governance and transboundary regionalization. Spatial partnership formations as democratic exit, loyalty and voice options? In O., Kramsch \& B., Hooper (Eds.). Cross-Border Governance in the European Union (pp. 157-170). Abingdon-New York, NY: Routledge. Weedon, C. (1987/1993). Feminist Practice and Poststructuralist Theory. Oxford: Blackwell.

Zielonka, J. (2006). Europe as Empire. The Nature of the Enlarged European Union. Oxford-New York, NY: Oxford University Press.

Zonneveld, W., \& Waterhout, B. (2009). EU Territorial Impact Assessment: Under what Conditions? OTB Research Institute, Delft University of Technology. Retrieved from https://www.rtpi.org.uk/media/5987/tiareport_zonneveld02072009.pdf 